\title{
A validated method to assess glutathione peroxidase enzyme activity
}

Mahmoud H. Hadwan ( $\sim$ mahmoudhadwan@gmail.com )

University of Babylon https://orcid.org/0000-0003-1958-7764

Ahmed Yasser Ahmed

University of Babylon

\section{Research Article}

Keywords: Bland-Altman plot, Box-Behnken design, CUPRAC method, glutathione, response surface methodology.

Posted Date: June 2nd, 2021

DOl: https://doi.org/10.21203/rs.3.rs-526347/v1

License: (1) This work is licensed under a Creative Commons Attribution 4.0 International License. Read Full License

Version of Record: A version of this preprint was published at Chemical Papers on August 22nd, 2021. See the published version at https://doi.org/10.1007/s11696-021-01826-1. 


\title{
A validated method to assess glutathione peroxidase enzyme activity
}

\author{
Ahmed Yasser Ahmed; Mahmoud Hussein Hadwan* \\ Chemistry Dept., College of Science, University of Babylon, Hilla city, Babylon Governorate, \\ p.o. 51002, Iraq
}

*Correspondence:

Email address: mahmoudhadwan@gmail.com

Email address: ahmedyassr51@gmail.com

Graphical abstract:
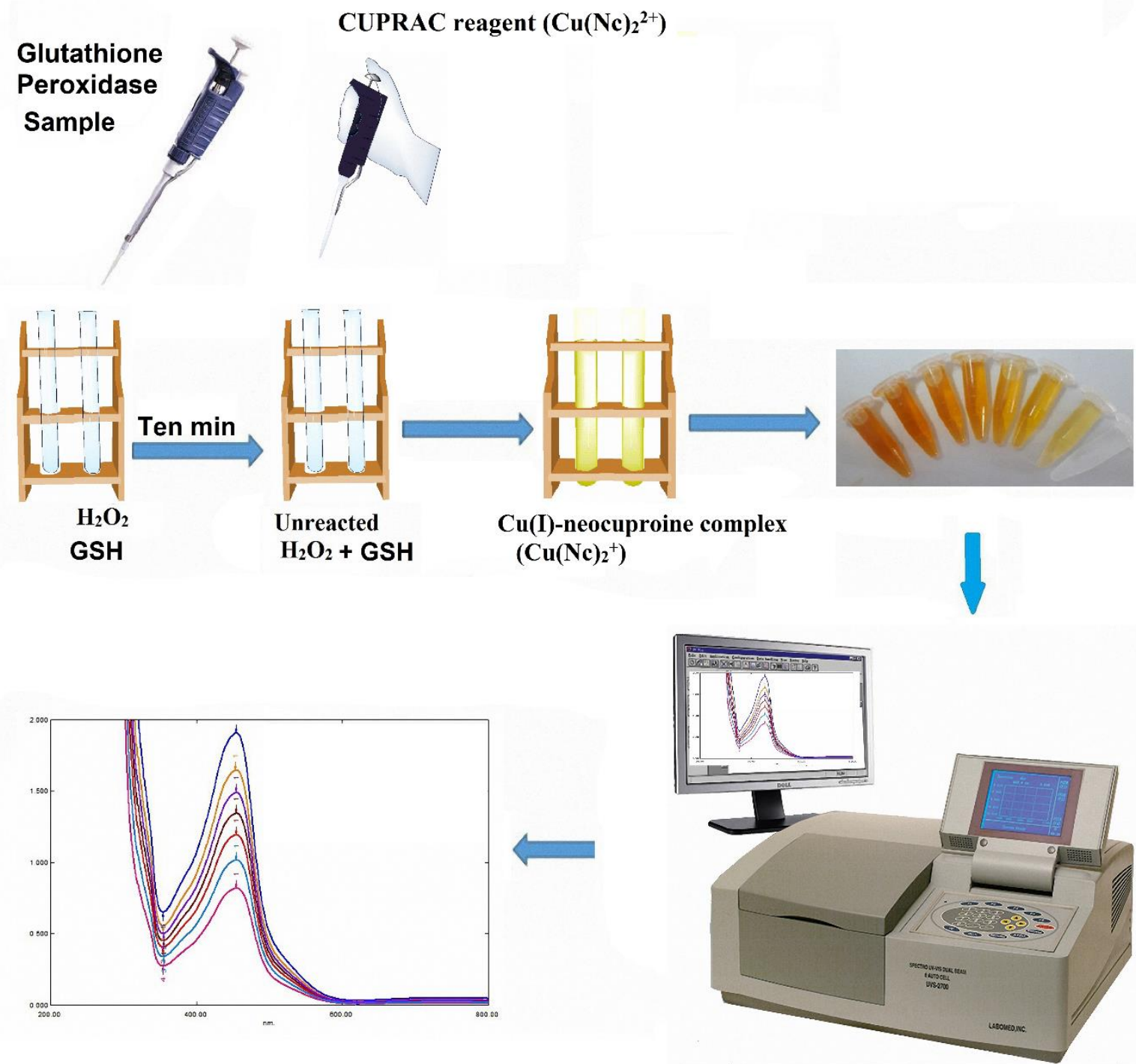


\title{
A validated method to assess glutathione peroxidase enzyme activity
}

\author{
Ahmed Yasser Ahmed; Mahmoud Hussein Hadwan* \\ Chemistry Dept., College of Science, University of Babylon, Hilla city, Babylon Governorate, \\ p.o. 51002, Iraq \\ *Correspondence: \\ Email address: mahmoudhadwan@gmail.com \\ Email address: ahmedyassr51@gmail.com
}

Received [Dates will be filled in by the Editorial office]

\begin{abstract}
:
This essay presents a reliable, effective and easy procedure for measuring glutathione peroxidase activity (Gpx). The enzyme samples were incubated with phosphate buffer, which included appropriate concentrations of glutathione and peroxide as substrates, to determine the Gpx activity. After a sufficient incubation time, the CUPRAC reagent $\left(\mathrm{Cu}(\mathrm{Nc})_{2}{ }^{2+}\right)$ was added to stop the enzyme's reaction. The unreacted substrates act to reduce $\mathrm{Cu}(\mathrm{II})$-neocuproine complex $\left(\mathrm{Cu}(\mathrm{Nc})_{2}{ }^{2+}\right)$ to strongly coloured $\mathrm{Cu}(\mathrm{I})$-neocuproine complex $\left(\mathrm{Cu}(\mathrm{Nc})_{2}{ }^{+}\right)$that was measured spectrophotometrically at $450 \mathrm{~nm}$ (CUPRAC method). The glutathione peroxidase activity was linked to a decrease in the absorbance of the coloured $\mathrm{Cu}(\mathrm{I})$-neocuproine complex $\left(\mathrm{Cu}(\mathrm{Nc})_{2}{ }^{+}\right)$.

The procedure uses the Box-Behnken design (BBD) to optimise the formation of the $\mathrm{Cu}(\mathrm{I})$-neocuproine complex $\left(\mathrm{Cu}(\mathrm{Nc})_{2}{ }^{+}\right)$. The response surface methodology (RSM) is used to determine the accuracy of the method. This new protocol was confirmed by applying a Bland-Altman plot analysis of Gpx activity in matched samples using the Gpx-DTNB assay. The correlation coefficient between the two protocols was 0.9967. This means that the new protocol was very accurate and on par with the comparison method.
\end{abstract}

Keywords: Bland-Altman plot, Box-Behnken design, CUPRAC method, glutathione, response surface methodology. 


\section{Introduction}

Glutathione peroxidases (Gpx) act to reduce hydroperoxides ( $\mathrm{ROOH})$ by glutathione (GSH):

$$
\mathrm{ROOH}+2 \mathrm{GSH} \rightarrow \mathrm{ROH}+\mathrm{H}_{2} \mathrm{O}+\mathrm{GSSG}
$$

$\mathrm{R}$ may be an aliphatic, aromatic, or hydrogen-containing organic group. $\mathrm{H}_{2} \mathrm{O}$, alcohol ( $\mathrm{ROH}$ ) (or a second $\mathrm{H}_{2} \mathrm{O}$ when $\mathrm{H}_{2} \mathrm{O}_{2}$ is the substrate), and glutathione disulphide (GSSG) are the products. The enzyme glutathione reductase is responsible for regenerating GSH from GSSG in the cell $[1,2]$. The glutathione peroxidase family (GPx1-8) catalyse the reduction of organic and inorganic peroxides by using reduced GSH. Proteins that contain selenocysteine make up five of the eight glutathione peroxidases (GPx1-4 and GPx6) [3]. The tendency of various GPxs to catalyse the degradation of hydroperoxides by thiols is their common denominator [4]. Gpx is a significant system to protect against endogenously and exogenously mediated lipid peroxidation that is present in many animal tissues. The enzyme is stoichiometric in selenium, and it reacts with several organic hydroperoxides as well as hydrogen peroxide [5].

Even though several protocols for assessing glutathione peroxidase activity have been established, only a few are still useful. To assess glutathione peroxidase activity in biological tissues, only two different test systems have been used. The first system [1, 6] was based on measuring $\mathrm{ROOH}$ or GSH consumption at regular interval. The second system monitors GSSG production by coupling to the glutathione reductase-catalysed reaction $[1,7]$. The decrease in NADPH concentration is continuously measured spectrophotometrically or fluorometrically $[6,7]$.

Ellman's reagent (DTNB) is most commonly used in the first system to colourimetrically evaluate glutathione consumption as a function of glutathione peroxidase activity [6]. Compared to other tests, the GPx-DTNB assay is insensitive [8] and Ellman's reagent is relatively unstable [9]. Moreover, the process is timeconsuming [10]. Flohé and Günzler [11], on the other hand, showed another polarographic method. It employed strong acid to stop enzyme-catalysed or spontaneous GSH-hydrogen peroxide reactions at a specified time (t). Polarography is then used to determine the GSH content. 
Ugar et al. [12] recommended a microplate-based method that reduced the $\mathrm{Cu}(\mathrm{II})$ neocuproine complex to highly coloured $\mathrm{Cu}(\mathrm{I})$-neocuproine complex by using unreacted GSH. Catalase enzyme with high activity was used to stop the Gpx reaction. The absorbance decrement was correlated with Gpx activity. The method was suitable to assess Gpx activity in pure samples but not for assessing its activity in biological tissues because this does not take into account the interference arising from the presence of the catalase enzyme. Glutathione peroxidase and catalase act on hydrogen peroxide as a common substrate. All previous methods work to block interference with the catalase enzyme by adding sodium azide, which inhibits the catalase enzyme selectively.

Fluorescent methods occupy an important part of the second system of methods used to estimate the Gpx activity. Weiss et al. [13] documented a fluorometric method to measure Gpx activity in less than $100 \mu \mathrm{g}$ of tissue. That assay depends on the fluorometric behaviour of $\mathrm{NADP}^{+}$that arises from the oxidised glutathione created by the Gpx reaction. Martinez et al. [14] developed a fluorometric procedure with high sensitivity that used the assay of oxidised glutathione with o-phthalaldehyde. Kamata et al. [15] developed a sensitive method to assess Gpx activity using the fluorometric reaction of oxidised glutathione with $\mathrm{N}$-(9-acridinyl) maleimide. The procedure was used to evaluate human plasma samples and liver homogenates.

Paglia and Valentino [7] were developed the most widely used protocol for measuring Gpx activity. It was based on the change of absorbance at $340 \mathrm{~nm}$ when NADPH is consumed by oxidised glutathione (GSSG). The protocol was modified by Lawrence and Burk [16] to study the activity of the Gpx enzyme in the liver supernatant of rats fed with a Se-deficient diet. The protocol was simple and selective, but the sensitivity was poor, and the enzyme and NADPH are costly [12]. Furthermore, NADPH $+\mathrm{H}^{+}$ seems to be a potent Gpx inhibitor [10]. Since proteins and DNA absorb UV light, the method cannot have precise results when calculating Gpx activity in biological tissues.

A simple method for determining Gpx enzyme activity is identified in this paper. Phosphate buffer was used to incubate the enzyme samples, which had appropriate concentrations of glutathione and peroxide as substrates. After appropriate incubation, the CUPRAC reagent $\left(\mathrm{Cu}(\mathrm{Nc})_{2}{ }^{2+}\right)$ was added to stop the enzyme's reaction. Unreacted substrates reduced the $\mathrm{Cu}(\mathrm{II})$-neocuproine $\left(\mathrm{Cu}(\mathrm{Nc})_{2}{ }^{2+}\right)$ complex to highly coloured 
$\mathrm{Cu}(\mathrm{I})$-neocuproine $\left(\mathrm{Cu}(\mathrm{Nc})_{2}{ }^{+}\right)$complex, which has a maximum absorbance at $450 \mathrm{~nm}$ (CUPRAC method). The Gpx activity was correlated inversely with the decrease of absorbance of coloured $\mathrm{Cu}(\mathrm{I})$-neocuproine $\left(\mathrm{Cu}(\mathrm{Nc})_{2}{ }^{+}\right)$complex.

The current protocol is precise, efficient, and trustworthy. The method is interferencefree, simple to implement in laboratory experiments, and appropriate for clinical diagnosis.

\section{Materials and Methods}

\section{Chemicals and materials}

Ammonium acetate, calcium chloride, copper(II) chloride, dipotassium phosphate $\left(\mathrm{K}_{2} \mathrm{HPO}_{4}\right)$, hydrochloric acid, sodium dihydrogen phosphate dihydrate $\left(\mathrm{NaH}_{2} \mathrm{PO}_{4}\right.$. $2 \mathrm{H}_{2} \mathrm{O}$ ), hydrogen peroxide (30\%), di-sodium hydrogen phosphate dihydrate $\left(\mathrm{Na}_{2} \mathrm{HPO}_{4} .2 \mathrm{H}_{2} \mathrm{O}\right)$, sodium azide, sodium hydroxide, sodium nitrate, and trichloroactetic acid were purchased from BDH.

Bovine serum albumin, glutathione, homocysteine, neocuproine (2,9-dimethyl-1,10phenanthroline) and tert-butyl hydroperoxide were purchased from Sigma-Aldrich.

Animals: The albino rats were obtained from Animal House, University of Babylon, Babylon governorate, Iraq. They were kept in well-ventilated cages with monitored light and humidity, as well as free access to regular food and water. The current study was conducted in accordance with the WSAVA Animal Welfare Recommendations [17].

\section{Reagents}

1. The phosphate buffer solution (100 mM M, pH 7.0) consisted of 1:1.5 volumes of $\mathrm{A}$ and $\mathrm{B}$ solutions. Solution A contained $13.62 \mathrm{~g}$ of $\mathrm{KH}_{2} \mathrm{PO}_{4}$ dissolved in 1 $\mathrm{L}$ of distilled water (D.W.). Solution B contained $17.8 \mathrm{~g}$ of $\mathrm{Na}_{2} \mathrm{HPO}_{4} .2 \mathrm{H}_{2} \mathrm{O}$ dissolved in $1 \mathrm{~L}$ of D.W. A $0.372 \mathrm{~g}$ EDTA and $0.6501 \mathrm{~g}$ of $\mathrm{NaN}_{3}$ was added to the final solution and mixed gently.

2. Reduced glutathione ( $4 \mathrm{mM}$ ) was prepared by dissolving $0.1228 \mathrm{~g}$ of reduced glutathione in $100 \mathrm{ml}$ of $100 \mathrm{mM}$ phosphate buffer solution (pH 7.0).

3. Hydrogen peroxide $\mathrm{H}_{2} \mathrm{O}_{2}(2 \mathrm{mM})$ was prepared daily, in $100 \mathrm{mM}$ phosphate buffer solution ( $\mathrm{pH}$ 7.0). The final concentration was prepared by using a molar extinction coefficient of $43.6 \mathrm{M}^{-1} \mathrm{~cm}^{-1}$ at $240 \mathrm{~nm}$. 
4. Copper(II) chloride $\left(10^{-2} \mathrm{M}\right)$ comprised $0.4262 \mathrm{~g}$ of $\mathrm{CuCl}_{2} \cdot 2 \mathrm{H}_{2} \mathrm{O}$ dissolved in $250 \mathrm{ml}$ of D.W.

5. Ammonium acetate buffer $\left(\mathrm{NH}_{4} \mathrm{Ac}\right)(1.816 \mathrm{M}, \mathrm{pH} 7.0)$ was composed of $35 \mathrm{~g}$ of $\mathrm{NH}_{4} \mathrm{Ac}$ dissolved in $250 \mathrm{ml}$ D.W.

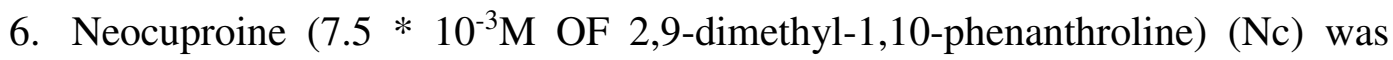
composed $0.039 \mathrm{~g} \mathrm{Nc}$ that was dissolved in $25 \mathrm{ml}$ of $96 \%$ ethanol.

7. Fresh working reagent (CUPRAC reagent) was used for the experiment. The reagent was composed of $\mathrm{Cu}(\mathrm{II}): \mathrm{Nc}: \mathrm{NH}_{4} \mathrm{Ac}$ at a ratio of $1: 1: 1(\mathrm{v} / \mathrm{v} / \mathrm{v})$.

\section{Instrument}

A Shimadzu 1800 spectrophotometer was used to take the measurements in the current study.

\section{Ethical agreement}

Ethics Committee (University of Babylon/ College of Science/ Iraq), Ref. no.: 5114 Date: $1 / 10 / 2020$.

\section{Glutathione peroxidase purification}

Rat's liver Gpx was purified, as described by Chafik et al. [18]. Gpx activity was measured using the GPx-DTNB assay [6]. The specific activity of Gpx was estimated to be about $1.2 \mathrm{U} \cdot \mathrm{mg}^{-1}$ protein.

\section{Tissue preparation}

After the animals were sacrificed, the livers were washed thoroughly and rinsed with ice. They were weighted in an objective equilibrium after being carefully blotted between folds of filter paper. A polytron homogeniser was used to prepare $10 \%$ of the homogenate in $0.1 \mathrm{M}$ phosphate buffer ( $\mathrm{pH}$ 7.0). Unbroken cells, cell debris, nuclei, mitochondria, and erythrocytes were removed from the homogenate by centrifugation at 10,000 rpm for 20 minutes. The Gpx level was measured in the supernatant.

\section{Detailed of procedure}

The details of the procedure are shown in table 1. 
Table 1. The details of the protocol used to measure glutathione peroxidase activity.

\begin{tabular}{lllll}
\hline \multicolumn{1}{c}{ Reagents } & Test & Control & STD & Blank \\
\hline Sodium phosphate buffer & $1500 \mu \mathrm{L}$ & $1900 \mu \mathrm{L}$ & $1600 \mu \mathrm{L}$ & $2000 \mu \mathrm{L}$ \\
\hline Reduced glutathione & $200 \mu \mathrm{L}$ & ---- & $200 \mu \mathrm{L}$ & ------ \\
\hline Sample & $100 \mu \mathrm{L}$ & $100 \mu \mathrm{L}$ & ------- & ------ \\
\hline
\end{tabular}

The reaction was initiated by adding peroxide:

\begin{tabular}{llll}
\hline Peroxide & $200 \mu \mathrm{L}$ & ---- & $200 \mu \mathrm{L}$
\end{tabular}

Mix by vortex and incubate for 10 minutes at $37^{\circ} \mathrm{C}$, after that, the reaction was terminated with $0.5 \mathrm{ml}$ of $8 \%$ TCA

Mix well and centrifuge for 15 minutes at $3000 \mathrm{xg}$, then remove $1 \mathrm{ml}$ of supernatant in a clean tube, and add:

\begin{tabular}{lllll}
\hline Working reagent & $3 \mathrm{ml}$ & $3 \mathrm{ml}$ & $3 \mathrm{ml}$ & $3 \mathrm{ml}$ \\
\hline
\end{tabular}

Absorbance was read against blank at $450 \mathrm{~nm}$ after $30 \mathrm{~min}$.

\section{Calculation}

Unit definition: one unit of GPx was defined as the amount of enzyme capable of oxidising $1.0 \mu$ mole GSH to GSSG per minute at $25^{\circ} \mathrm{C}, \mathrm{pH} 7.0[1,6]$.

The residual glutathione concentration in test tube $=\left(\frac{A \text { Test }- \text { A Control }}{A \text { STD }}\right) \times$ Conc. of STD The concentration of standard glutathione was $400 \mu \mathrm{M}$.

Also, the residual glutathione concentration in the test tube could be calculated from the glutathione standard curve (fig. 1). Gpx activity equals the number of micromoles of consumed glutathione.

Glutathione peroxidase activity $(\mathrm{U} / \mathrm{L})=$ $\left(\frac{\text { Conc.of GSH in STD-Conc.of residual GSH in test tube }}{\text { time }(10 \mathrm{~min})}\right) \times\left(\frac{\text { Total volume }(\mathrm{ml})}{\text { Volume of the sample }(\mathrm{ml})}\right) \times \mathrm{D} . \mathrm{f}$.

\section{Standard curve preparation}

To create a standard curve for the assay, the stock solution of the standards (glutathione and peroxide) were diluted with the phosphate buffer (0.1 M, pH 7.0) according to the layout in table 2. Once each standard tube was created and mixed, $1000 \mu \mathrm{L}$ of each was added to the three $\mathrm{ml}$ of working solution according to the protocol listed in table 1 . Absorbance was read against blank at $450 \mathrm{~nm}$ after $30 \mathrm{~min}$ (as shown in fig. 1). 
Table 2: Standard Curve Preparation

\begin{tabular}{|c|c|c|c|c|c|}
\hline Standard & $\begin{array}{l}\text { Volume of } \\
\text { Glutathione } \\
4 \mathrm{mM}\end{array}$ & $\begin{array}{l}\text { Final } \\
\text { concentration } \\
\text { of } \\
\text { glutathione }\end{array}$ & $\begin{array}{l}\text { Volume of } \\
\text { peroxide } \\
2 \mathrm{mM}\end{array}$ & $\begin{array}{l}\text { Final } \\
\text { concentration } \\
\text { of peroxide }\end{array}$ & $\begin{array}{l}\text { Volume of } \\
\text { phosphate } \\
\text { buffer } \\
\text { solution }\end{array}$ \\
\hline S1 & $400 \mu 1$ & $800 \mu \mathrm{M}$ & $400 \mu \mathrm{l}$ & $400 \mu \mathrm{M}$ & $1200 \mu \mathrm{l}$ \\
\hline S2 & $300 \mu \mathrm{l}$ & $600 \mu \mathrm{M}$ & $300 \mu \mathrm{l}$ & $300 \mu \mathrm{M}$ & $1400 \mu 1$ \\
\hline S3 & $200 \mu \mathrm{l}$ & $400 \mu \mathrm{M}$ & $200 \mu \mathrm{l}$ & $200 \mu \mathrm{M}$ & $1600 \mu 1$ \\
\hline S4 & $150 \mu \mathrm{l}$ & $300 \mu \mathrm{M}$ & $150 \mu \mathrm{l}$ & $150 \mu \mathrm{M}$ & $1700 \mu 1$ \\
\hline S5 & $100 \mu \mathrm{l}$ & $200 \mu \mathrm{M}$ & $100 \mu \mathrm{l}$ & $100 \mu \mathrm{M}$ & $1800 \mu 1$ \\
\hline S6 & $50 \mu 1$ & $100 \mu \mathrm{M}$ & $50 \mu 1$ & $50 \mu \mathrm{M}$ & $1900 \mu \mathrm{l}$ \\
\hline S7 & $25 \mu 1$ & $50 \mu \mathrm{M}$ & $25 \mu 1$ & $25 \mu \mathrm{M}$ & $1950 \mu \mathrm{l}$ \\
\hline S8 & $5 \mu \mathrm{l}$ & $10 \mu \mathrm{M}$ & $5 \mu 1$ & $5 \mu \mathrm{M}$ & $1990 \mu \mathrm{l}$ \\
\hline B & ------ & ------ & ----- & ----- & $2000 \mu 1$ \\
\hline
\end{tabular}

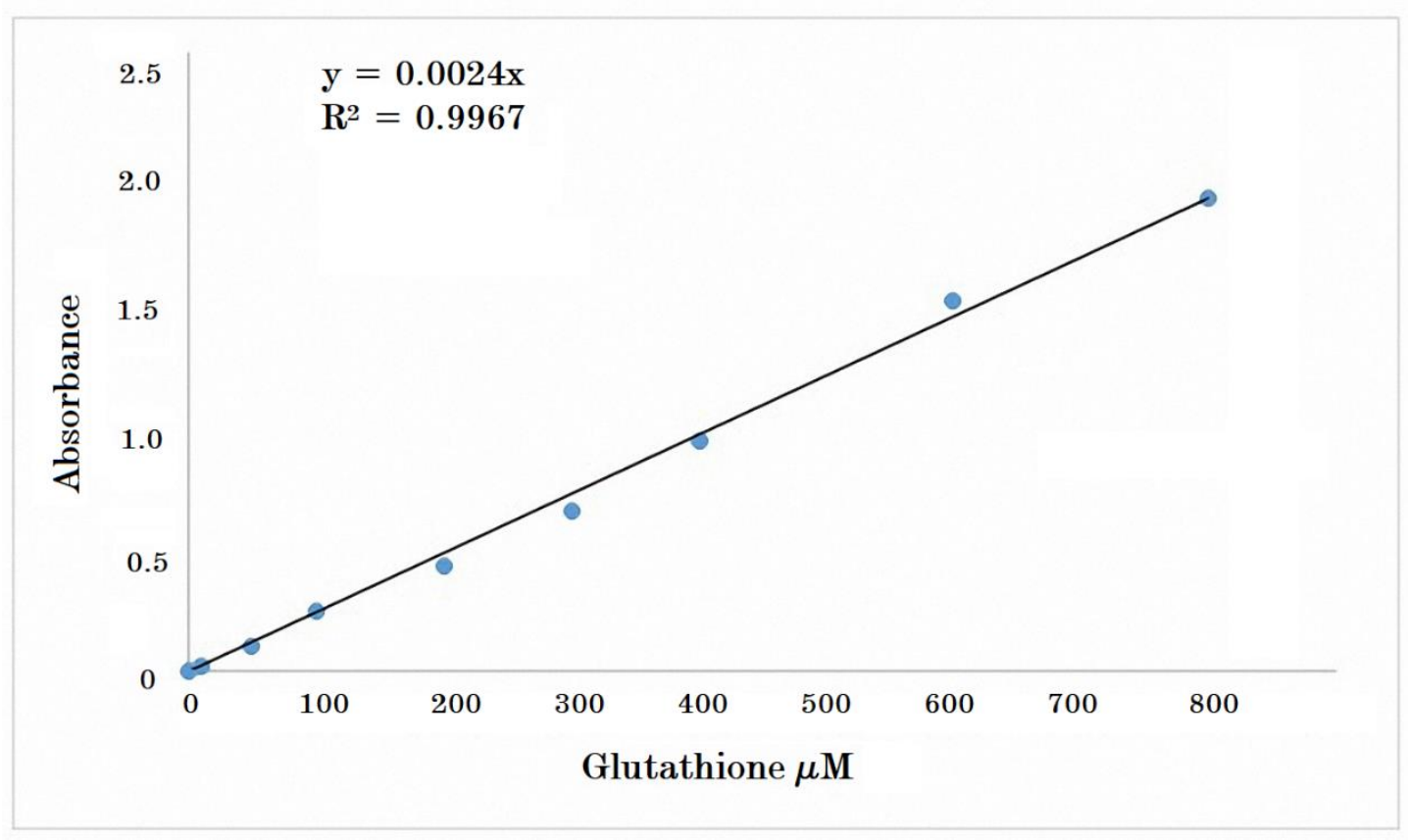

Fig. 1. The standard curve of glutathione obtained by using the current protocol.

\section{Performance of the method}

Performance of the current method was achieved according to the guideline on bioanalytical method validation from the Committee for Medicinal Products for Human Use [19].

\section{Optimising the protocol}

To optimise the Gpx-CUPRAC protocol, the BBD was used to apply RSM. To design the Gpx assay experiment and optimise the method, the statistical parameters were calculated using Chemoface software, Version 1.5 [20]. The enzymatic reaction was 
performed with Gpx solution (500 U.L $\mathrm{L}^{-1}$ ), which was prepared fresh before the experiment by dissolving $417 \mathrm{mg}$ of Gpx standard in $100 \mathrm{ml}$ of $100 \mathrm{mM}$ phosphate buffer solution ( $\mathrm{pH} 7.0)$. The Gpx-DTNB procedure $[6,11]$ was used to adjust the final Gpx activity to 500 U.L ${ }^{-1}$. The independent variables were glutathione, peroxide, and neocuproine concentrations (Table 3), and the dependent variable was the obtained Gpx activity compared to the current spectrophotometric protocol.

The mathematical modelling of a second-order polynomial equation was used to determine the interaction between the dependent and independent variables.

$$
\mathrm{Y}=\beta_{0}+\sum \beta_{\mathrm{i}} \mathrm{X}_{\mathrm{i}}+\sum \beta_{\mathrm{ii}} \mathrm{X}_{\mathrm{i}}^{2}+\sum \beta_{\mathrm{ij}} X_{\mathrm{i}} \mathrm{X}_{\mathrm{j}}+\varepsilon
$$

where $\mathrm{Y}$ refers to the response variable, $\mathrm{XiXj}$ refers to the independent variables, and $\beta 0, \beta \mathrm{i}, \beta \mathrm{ii}$, and $\beta \mathrm{ij}$ refer to the intercept, linear, quadratic and interaction coefficients, respectively. Random error is represented by the symbol $\varepsilon$.

Table 3. shows the results of using the Box-Behnken design to optimise the glutathione peroxidase activity assay. The independent variables were glutathione, peroxide, and neocuproine concentrations, and the dependent variable was glutathione peroxidase activity based on current spectrophotometric sensitivity.

\begin{tabular}{ccccc}
\hline Run & $\begin{array}{c}\text { Glutathione } \\
\text { Concentration } \\
\mathrm{mM}\end{array}$ & $\begin{array}{c}\text { Peroxide } \\
\text { Concentration } \\
\mathrm{mM}\end{array}$ & $\begin{array}{c}\text { Neocuproine } \\
\text { Concentration } \\
\mathrm{mM}\end{array}$ & $\begin{array}{c}\text { Glutathione } \\
\text { Peroxidase } \\
\text { Activity } \\
\text { (U/L) }\end{array}$ \\
\hline 1 & 2 & 1 & 5 & 401 \\
\hline 2 & 2 & 1 & 10 & 473 \\
\hline 3 & 2 & 3 & 5 & 482 \\
\hline 4 & 2 & 3 & 10 & 482 \\
\hline 5 & 6 & 1 & 5 & 429 \\
\hline 6 & 6 & 1 & 10 & 464 \\
\hline 7 & 6 & 3 & 5 & 491 \\
\hline 8 & 6 & 3 & 10 & 508 \\
\hline 9 & 0.636 & 2 & 7.5 & 446 \\
\hline 10 & 7.364 & 2 & 7.5 & 508 \\
\hline 11 & 4 & 0.318 & 7.5 & 410 \\
\hline 12 & 4 & 3.682 & 7.5 & 517 \\
\hline 13 & 4 & 2 & 3.296 & 446 \\
\hline 14 & 4 & 2 & 11.705 & 500 \\
\hline 15 & 4 & 2 & 7.5 & 500 \\
\hline 16 & 4 & 2 & 7.5 & 497 \\
\hline 17 & 4 & 2 & 7.5 & 502 \\
\hline
\end{tabular}




\section{Accuracy, selectivity, and reproducibility}

Three kinds of interfering biochemicals were dissolved in four separate flasks to test the accuracy of the new Gpx procedure. The first included $100 \mathrm{mM}$ phosphate buffer solution ( $\mathrm{pH} 7.4$ ), the second $5 \mathrm{mM}$ sucrose, glucose, mannose, galactose, and ribose, the third $5 \mathrm{mM}$ isoleucine, leucine, aspartic acid, methionine, and valine, and the fourth $3 \%$ casein and $3 \%$ bovine albumin. The phosphate buffer was used to dissolve all the interfering biomolecules. One $\mathrm{ml}$ of $3000 \mathrm{U} / \mathrm{l} \mathrm{Gpx}$ enzyme was combined with $9 \mathrm{ml}$ of the solutions containing possibly interfering biochemicals in an enzymatic reaction. Using the Gpx-DTNB method, the activity of Gpx was calibrated to 300 U/l. The GpxCUPRAC protocol recovery was calculated for each possible interfering biomolecule. The association between relative percentage errors and interfering biological substances is shown in Table 4. Several biological samples were used to test the current method's inter-and intra-day reproducibility, and the results were shown using RSD.

\section{Signal stability}

A Gpx solution (150 U.L $\mathrm{L}^{-1}$ ) was used to study the stabilisation of the coloured chelate complex. After adding the working solution, the absorbance reading at $450 \mathrm{~nm}$ was measured after 15 minutes, 30 minutes, 45 minutes, 60 minutes, 5 hours, one day, three days and one week.

\section{Sensitivity and linearity}

The linearity and sensitivity of the protocol were tested using a range of Gpx activities $\left(0,5,10,25,50,100,200,400,600,700\right.$ and $1000{\mathrm{U} . L^{-1}}^{-1}$. The linearity was assessed by comparing it to the Gpx-DTNB method $[6,11]$ using a web-based program for bias assessment and comparison of analytical methods [21]. Limits of quantitation (LOW) and detection (LOD) were used to calculate the sensitivity of the Gpx-CUPRAC assay [22].

\section{Validation}

The Passing-Bablok regression [23] and Bland-Altman analysis [24] were used to compare the Gpx-CUPRAC method to the Gpx-DTNB method. The QiMacros program linked to Microsoft Excel 2016 was used for mathematical analyses (QiMacros, Know Ware International, Denver, USA). 


\section{Results and Discussion}

\section{CUPRAC reagent as a suitable probe to measure Gpx activity [the Gpx-CUPRAC method]}

By using the cupric neocuproine complex $\left(\mathrm{Cu}(\mathrm{Nc})_{2}{ }^{2+}\right)$ as a suitable chromogenic oxidising probe, the present work explains a basic procedure to assay Gpx activity in biological samples (CUPRAC method). Apak et al. [25] introduced the CUPRAC method to calculate antioxidant capacity. To establish Gpx activity, the enzyme samples were incubated with phosphate buffer, which contains suitable concentrations of the glutathione and peroxide as substrates. To stop the enzyme's reaction, the CUPRAC reagent $\left(\mathrm{Cu}(\mathrm{Nc})_{2}{ }^{2+}\right)$ was added after a suitable incubation time.

Reducing the $\mathrm{Cu}(\mathrm{II})$-neocuproine $\left(\mathrm{Cu}(\mathrm{Nc})_{2}{ }^{2+}\right)$ complex to coloured $\mathrm{Cu}(\mathrm{I})$-neocuproine $\left(\mathrm{Cu}(\mathrm{Nc})_{2}{ }^{+}\right)$complex by the unreacted substrates was quantified spectrophotometrically at $450 \mathrm{~nm}$ (CUPRAC method), as shown in Scheme 1. The decrease of absorbance of coloured $\mathrm{Cu}(\mathrm{I})$-neocuproine $\left(\mathrm{Cu}(\mathrm{Nc})_{2}{ }^{+}\right)$complex correlated with the $\mathrm{Gpx}$ activity. The Gpx enzyme reaction formed the $\mathrm{Cu}(\mathrm{I})$-neocuproine $\left(\mathrm{Cu}(\mathrm{Nc})_{2}{ }^{+}\right)$complex, which had a single peak at $450 \mathrm{~nm}$. The absorbance was specifically associated with the unreacted substrates (glutathione and peroxide), as shown in Figure 2.

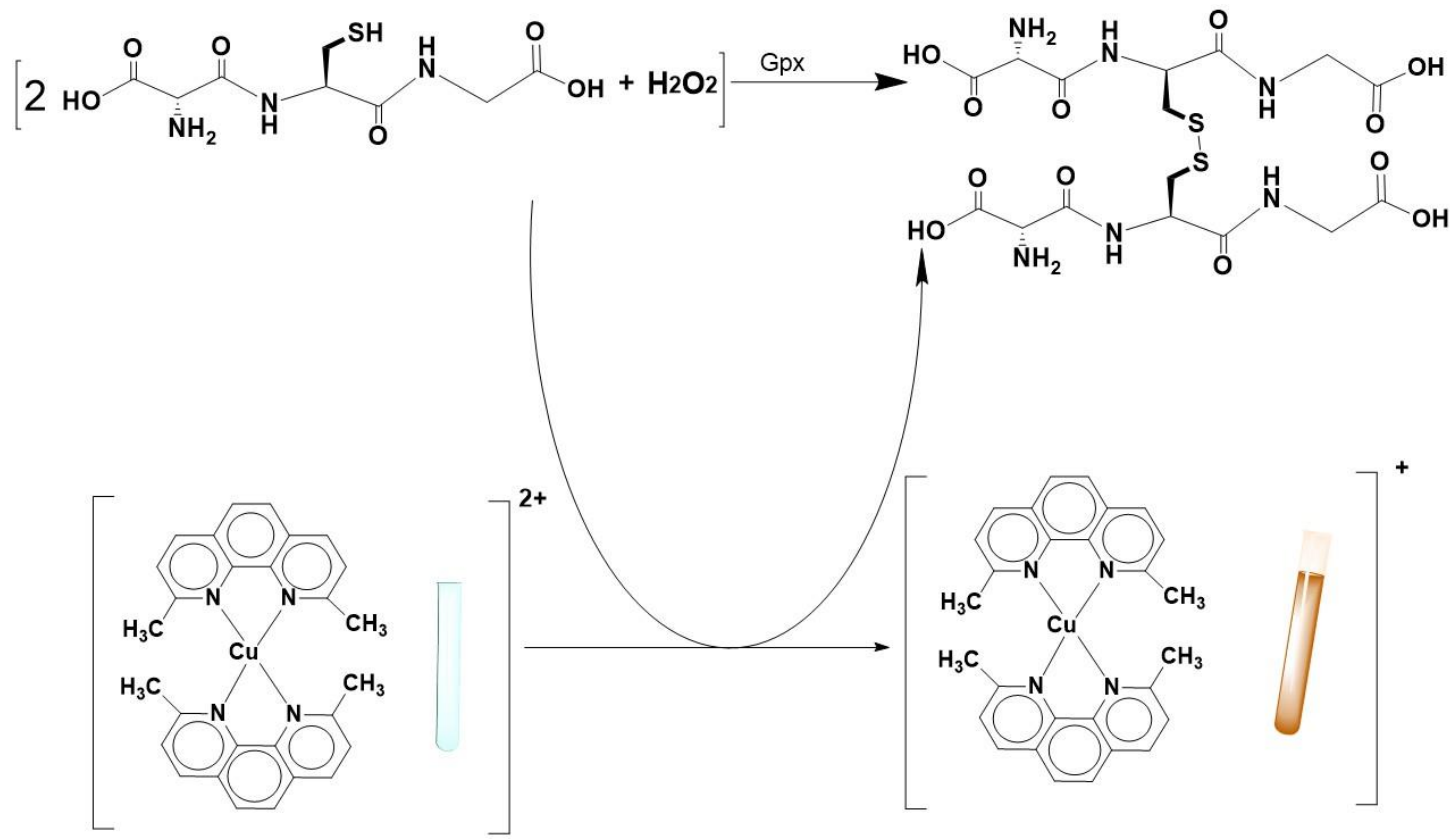

Scheme 1: Glutathione peroxidase uses peroxide to convert reduced glutathione (GSH) to oxidised glutathione (GSSG). $\mathrm{Cu}$ (II)-neocuproine complex reacts with unreacted substrates (glutathione and peroxide) to produce yellow-orange $\mathrm{Cu}(\mathrm{I})$-neocuproine stable complex. 


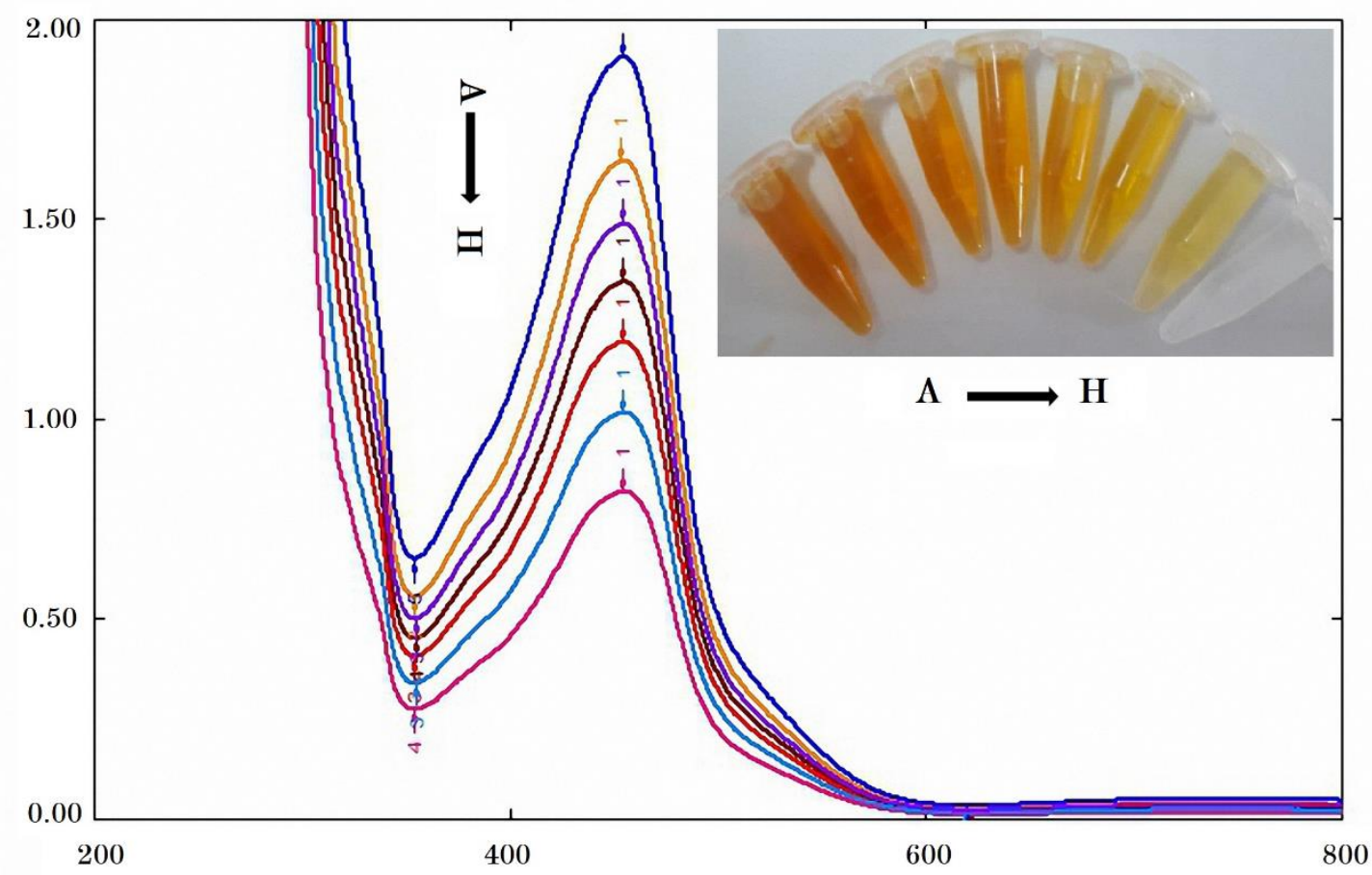

Fig. 2. Glutathione enzyme activity correlated inversely with the intensity of the formed $\mathrm{Cu}(\mathrm{I})$-neocuproine $\left(\mathrm{Cu}(\mathrm{Nc})_{2}{ }^{+}\right)$complex. Absorption spectra was achieved by reducing $\left(\mathrm{Cu}(\mathrm{Nc})_{2}{ }^{2+}\right)$ to coloured $\mathrm{Cu}(\mathrm{I})$-neocuproine complex $\left(\mathrm{Cu}(\mathrm{Nc})_{2}{ }^{+}\right)$as a result of adding 1 $\mathrm{ml}$ of the solution prepared by mixing a suitable concentration of glutathione (GSH) with peroxide $\left(\mathrm{H}_{2} \mathrm{O}_{2}\right)$. (a) to (h) represent $\{(800 / 400),(700 / 350),(600 / 300),(550 / 275)$, (500/250), (450/225), (400/200)\} $\mu \mathrm{M}$ of $\left(\mathrm{GSH} / \mathrm{H}_{2} \mathrm{O}_{2}\right)$.

\section{Optimising the Gpx-CUPRAC assay}

To achieve the optimum conditions, statistical methods were adapted with the BoxBehnken design (BBD) [26]. To optimise the Gpx-CUPRAC assay, BBD is an important measuring method with three central points to optimise glutathione, peroxide, and neocuproine concentrations to achieve optimal Gpx activity (see Table 3). The regression model for the Gpx-CUPRAC assay was determined using the analysis of variance (ANOVA) of the response surface methodology (RSM), as shown in Table 4. The model's F-value (12.82) showed that it was significant, while the lack-of-fitness Fvalue (2.8405) showed that it was not significant as compared to the related p-value. The significance of model terms was proved by obtained $p$-value $(p=0.0019)$.

The adjusted response (Adjusted $\mathrm{R}^{2}=0.9918$ ) was in acceptable agreement with the coefficient predicted response (Predicted $\mathrm{R}^{2}=0.9482$ ). As a result, the Gpx-CUPRAC assay's ANOVA showed that the specific correlation between the independent variables of the proposed model was appropriate for description and highly significant. 
To investigate the graphical results of the independent variables, contour diagrams and three dimensional (3D) of the BBD were used. When the third factor was constant, the creation of $2 \mathrm{D}$ and $3 \mathrm{D}$ graphs at the midpoint stage was based on a combination of two variables. In the response plot in Fig. $3 \mathrm{a}-\mathrm{f}$, the relationships between the variables (glutathione, peroxide, and neocuproine concentrations) are depicted. All the figures exhibited good significant curvature. Gpx activity was optimum at $4 \mathrm{mmol} \mathrm{L}^{-1}$ glutathione, $2 \mathrm{mmol} \mathrm{L^{-1 }}$ peroxide, and $7.5 \mathrm{mmol} \mathrm{L}^{-1}$ neocuproine concentrations. The actual activity level was $500 \mathrm{U} / \mathrm{L}$. The actual value was consistent with the predicted value, indicating that the RSM investigation was reliable and well-suited to experimental conditions.

Table 4. ANOVA values for the Gpx-CUPRAC assay's experimental variables.

\begin{tabular}{|c|c|c|c|c|c|}
\hline & $\begin{array}{ll}\begin{array}{l}\text { Sum } \\
\text { squares }\end{array} & \text { of } \\
\end{array}$ & $\begin{array}{l}\text { Degree of } \\
\text { freedom }\end{array}$ & $\begin{array}{l}\text { Mean } \\
\text { square }\end{array}$ & F-value & p-value \\
\hline Regression & $1.9322 \mathrm{e}+03$ & 9 & $2.1469 e+03$ & 12.8227 & 0.0019 \\
\hline Residual & $1.1720 \mathrm{e}+03$ & 7 & 167.4265 & & \\
\hline Lack-of-fit & $1.0273 \mathrm{e}+03$ & 5 & 205.4637 & 2.8405 & 0.2806 \\
\hline Pure error & 144.6667 & 2 & 72.3333 & & \\
\hline Total & $2.0494 \mathrm{e}+04$ & 16 & & & \\
\hline $\mathrm{R}^{2}$ & 0.9428 & & & & \\
\hline $\begin{array}{c}\text { Explainable } \\
\mathrm{R}^{2}\end{array}$ & 0.9918 & & & & \\
\hline
\end{tabular}



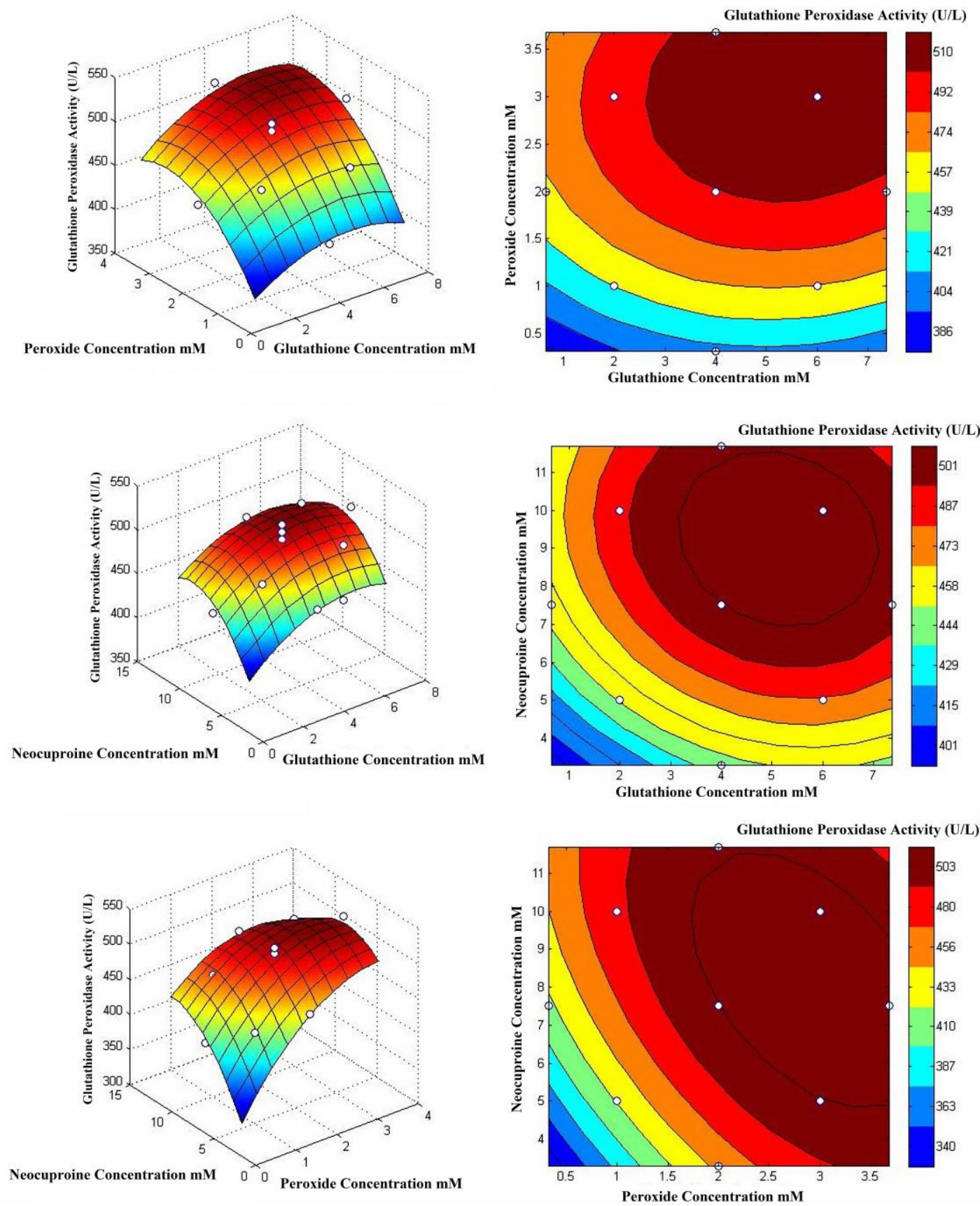

Fig. 3. 3D surface plot graphs and contours, demonstrating the interactions between glutathione concentration, peroxide concentration, and neocuproine concentration. The relationships between the variables (glutathione, peroxide, and neocuproine concentrations) are depicted in (a) through (f).

\section{Signal stability}

The coloured complex in the current study was remarkably stable at room temperature. At $25{ }^{\circ} \mathrm{C}$, the CUPRAC complex's $450 \mathrm{~nm}$ absorbance remained remarkably stable for more than a week. 


\section{Linearity and sensitivity}

According to the results shown in Fig 4, the Gpx-CUPRAC method was linear $(\mathrm{y}=$ $1.0006 \mathrm{x}$ ) within the range of $2-1000 \mathrm{U} . \mathrm{L}^{-1}$ of Gpx activity (Pearson's $r=0.999$ ). The LOQ (1 U.L $\left.{ }^{-1}\right)$ and LOD (3 U.L $\left.{ }^{-1}\right)$ values demonstrated the high sensitivity of the GpxCUPRAC assay. The linearity of the new method was like that of the Gpx-DTNB assay.

Figure 4 The Gpx activity of diluted tissue homogenates that were obtained by using the Gpx-CUPRAC method compared to the values achieved using the GPx-DTNB method.

\section{Selectivity, reproducibility, and accuracy of the Gpx-CUPRAC method}

The findings in Table 5 showed that the analysed biomolecules cannot interact with the Gpx-CUPRAC assay. The current method differs from previous methods for determining Gpx activity because it does not interfere with biomolecules. The current assay employs a control test tube to eliminate interference caused by organic biomolecules in the sample containing Gpx enzyme activity. In the current procedure, the absorbance of the test tube belongs to two kinds of compounds: unreacted substrates and sample interferences. The absorbance of the control test tube corresponds to interference compounds only. We excluded the interference of any compound that could reduce $\mathrm{Cu}(\mathrm{II})$-neocuproine complex $\left(\mathrm{Cu}(\mathrm{Nc})_{2}{ }^{2+)}\right.$ to coloured $\mathrm{Cu}(\mathrm{I})$-neocuproine complex $\left(\mathrm{Cu}(\mathrm{Nc})_{2}^{+}\right)$by subtracting the absorbance of the control test tube from the absorbance of the test tube. That means the remaining absorbance was exclusively for unreacted substrates.

Table 5. By using the Gpx-CUPRAC assay to assess Gpx activity, there is a relationship between relative percentage error and interfering biological interferences.

\begin{tabular}{cccc}
\hline & $\begin{array}{c}\text { Added Gpx } \\
\mathrm{U} / \mathrm{l}\end{array}$ & $\begin{array}{c}\text { Found Gpx } \\
\mathrm{U} / \mathrm{l}\end{array}$ & $\begin{array}{c}\text { Relative error } \\
(\%)\end{array}$ \\
\hline Volumetric flask 1 & 300 & 300 & 0.00 \\
\hline Volumetric flask 2 & 300 & 302 & 0.66 \\
\hline Volumetric flask 3 & 300 & 303 & 1.0 \\
\hline Volumetric flask 4 & 300 & 305 & 1.66 \\
\hline
\end{tabular}

The Gpx-CUPRAC assay was used to determine the Gpx activity of homogenates of liver tissue. The findings revealed that Gpx activity was elevated as predicted in liver tissue homogenates (Fig. 5). The Gpx-CUPRAC method demonstrated reasonable inter-day $(\mathrm{RSD} \%=2.2 .8 \%-3.2 \%)$ and intra-day $(\mathrm{RSD} \%=2.7 \%-3.8 \%)$. 


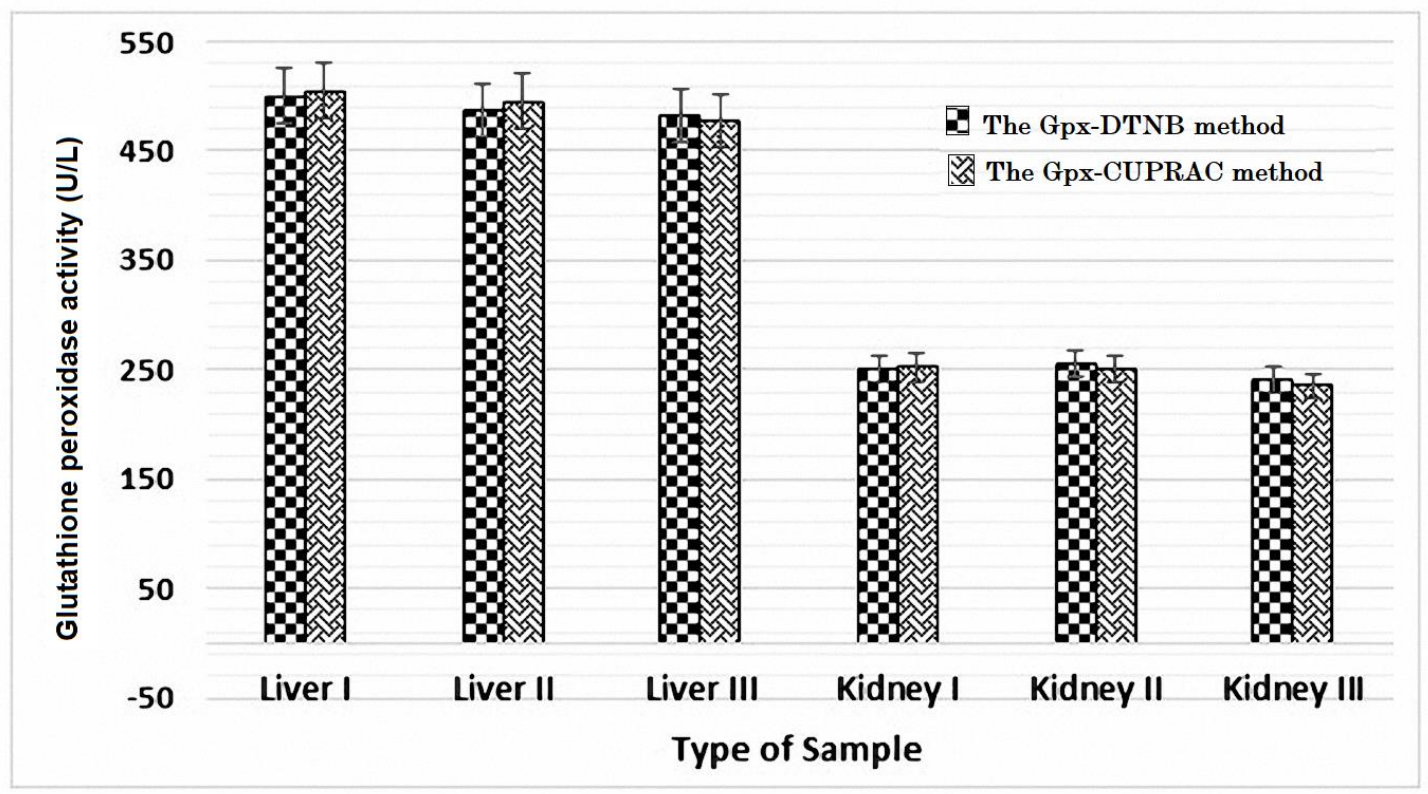

Fig. 5. Comparison of Gpx activity of diluted tissue homogenates that were obtained by the Gpx-CUPRAC method and the GPx-DTNB method.

Gpx activity assessment is a useful parameter for evaluating the liver's ability to reduce the susceptibility to oxidative stress. Furthermore, several scientific experiments have focused on Gpx activity in the livers of some types of lab animals to assess the oxidative stress inclination [27, 28].

\section{Validation}

Using matched enzymatic samples, Bland-Altman plot analyses (QI Macros, 2016) were used to compare the Gpx activity assessed by the present method with the Gpx activity assessed by the GPX-DTNB process [6]. Bland-Altman plot shows the relative differences between Gpx-CUPRAC and GPX-DTNB methods, as well as the mean relative bias (Fig. 6). The correlation coefficient between the two protocols was 0.9994 . This means that the new protocol is almost as accurate as the reference protocol. The comparison between the Gpx-CUPRAC method and the GPx-DTNB method using the Passing-Bablok similarity analysis showed a good agreement correlation (Fig. 7). 


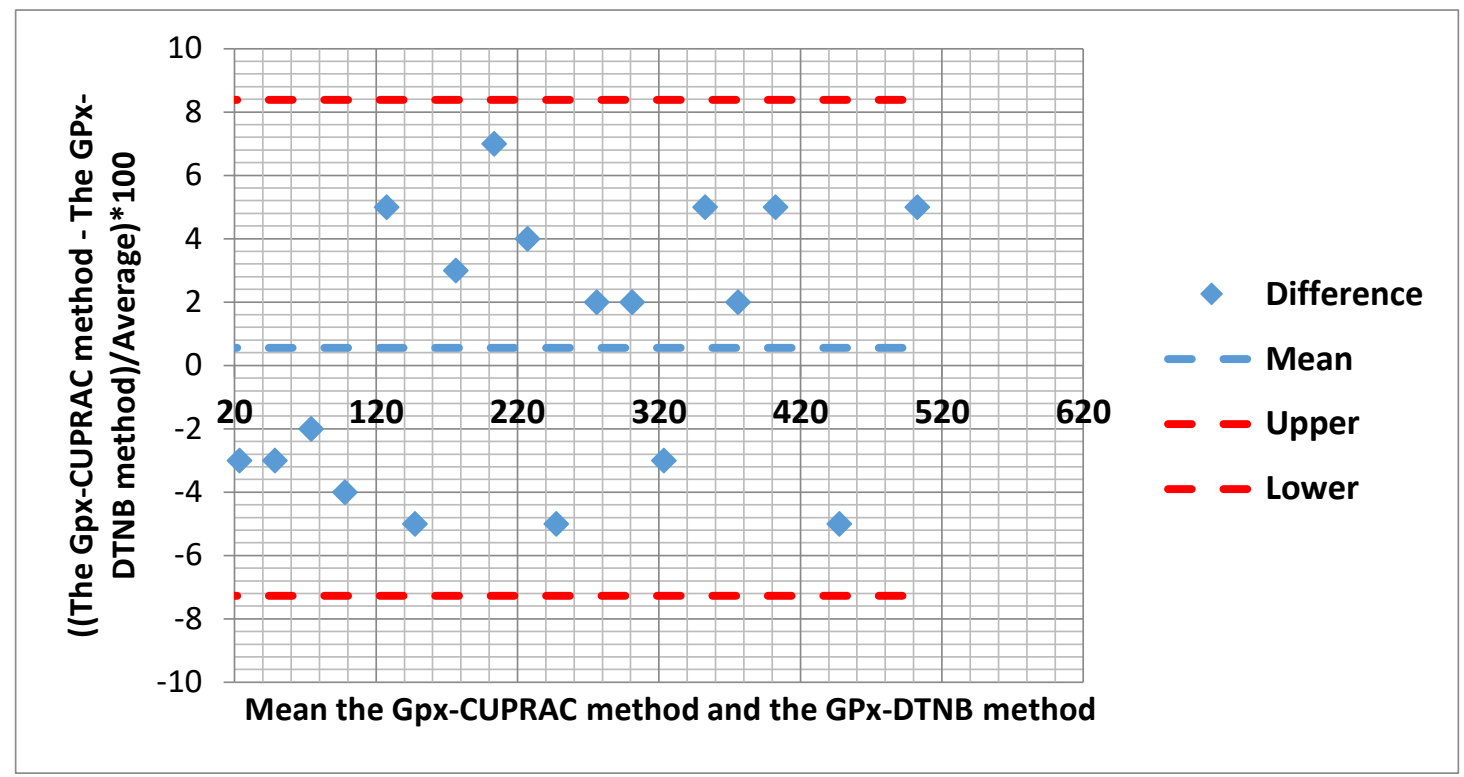

Fig. 6. Bland-Altman plot shows the relative differences between the Gpx-CUPRAC and GPX-DTNB protocols, as well as the mean relative bias.

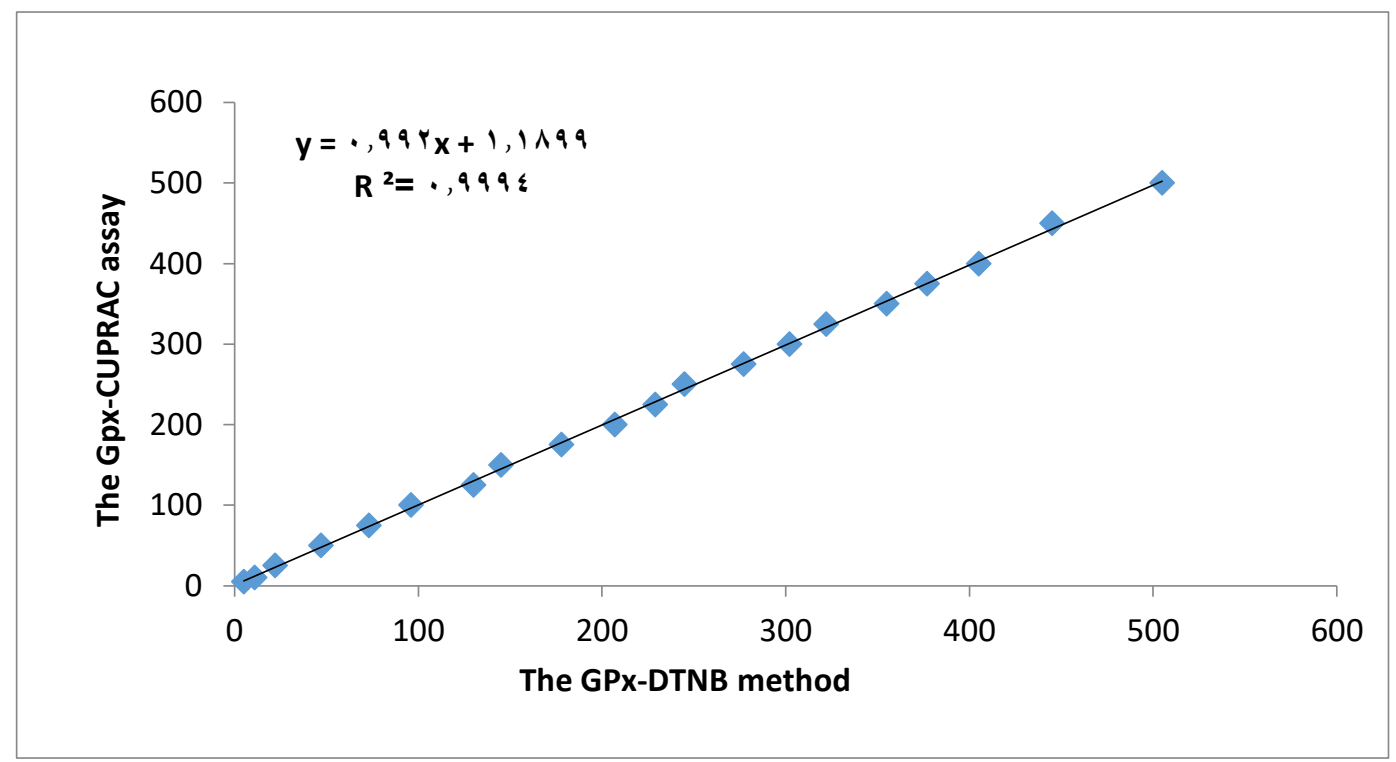

Fig. 7. Gpx activities were measured using the Gpx-CUPRAC and GPx-DTNB methods over a series of Gpx dilutions.

\section{Conclusion}

In this research, a simple and accurate protocol for calculating Gpx activity with a single reagent solution was developed. The BBD calculated the optimum glutathione, peroxide, and neocuproine concentrations. The new method is free of the interference that can arise when proteins, amino acids, and sugars are present. The CUPRAC assay's working solution allows for calculating Gpx activity at low concentrations of substrate. 


\section{Competing financial interests}

The author declares no competing financial interests.

\section{Acknowledgment}

We thank all of our colleagues for their continuous encouragement and helpful scientific comments.

\section{References:}

1. Mannervik B. [60] Glutathione peroxidase. Methods in enzymology. 1985 Jan 1;113:490-5.

2. Brigelius-Flohé, Regina, and Matilde Maiorino. "Glutathione peroxidases." Biochimica et Biophysica Acta (BBA)-General Subjects 1830.5 (2013): 3289-3303.

3. Chang, Caroline, et al. "Extracellular glutathione peroxidase GPx3 and its role in cancer." Cancers 12.8 (2020): 2197.

4. Brigelius-Flohé R, Flohé L. Regulatory phenomena in the glutathione peroxidase superfamily. Antioxidants \& redox signaling. 2020 Sep 1;33(7):498-516.

5. Wendel A. [44] Glutathione peroxidase. In Methods in enzymology 1981 Jan 1 (Vol. 77, pp. 325-333). Academic Press.

6. Austin, L.; Arthur, H.; De Niese, M.; Gursinghe, A.; Baker, M.S. Micromethods in single muscle fibers: 2. Determination of glutathione reductase and glutathione peroxidase. Anal. Biochem. 1988, 174, 575-579.

7. Paglia DE, Valentine WN. Studies on the quantitative and qualitative characterization of erythrocyte glutathione peroxidase. The Journal of laboratory and clinical medicine. $1967 \mathrm{Jul}$ 1;70(1):158-69.

8. Rover Jr, L.; Kubota, L.T.; Höehr, N.F. Development of an amperometric biosensor based on glutathione peroxidase immobilized in a carbodiimide matrix for the analysis of reduced glutathione from serum. Clin. Chim. Acta 2001, 308, 55-57

9. Piggott AM, Karuso P. Fluorometric assay for the determination of glutathione reductase activity. Analytical chemistry. 2007 Nov 15;79(22):8769-73.

10. Zakowski JJ, Tappel AL. A semiautomated system for measurement of glutathione in the assay of glutathione peroxidase. Analytical biochemistry. 1978 Sep 1;89(2):430-6.

11. Flohé L, Günzler WA. [12] Assays of glutathione peroxidase. Methods in enzymology. 1984 Jan 1;105:114-20.

12. Ugar M, Tufan AN, Altun M, Guclu K, Ozyurek M. Glutathione peroxidase activity of biological samples using a novel microplate-based method. Current Analytical Chemistry. 2018 Oct 1;14(5):512-8.

13. Weiss C, Maker HS, Lehrer GM. Sensitive fluorometric assays for glutathione peroxidase and reductase. Analytical biochemistry. 1980 Aug 1;106(2):512-6.

14. Martinez JI, Launay JM, Dreux C. A sensitive fluorimetric microassay for the determination of glutathione peroxidase activity. Application to human blood platelets. Analytical biochemistry. 1979 Sep 15;98(1):154-9.

15. Kamata T, Akasaka K, Ohrui H, Meguro H. Fluorometric assay of glutathione peroxidase activity in liver and plasma with $\mathrm{N}$-(9-acridinyl) maleimide. Bioscience, biotechnology, and biochemistry. 1994 Jan 1;58(5):878-80.

16. Lawrence RA, Burk RF. Glutathione peroxidase activity in selenium-deficient rat liver. Biochemical and biophysical research communications. 1976 Aug 23;71(4):952-8.

17. Ryan S, Bacon H, Endenburg N, Hazel S, Jouppi R, Lee N, Seksel K, Takashima G. WSAVA Animal Welfare Guidelines. Journal of Small Animal Practice. 2019 May 1;60(5):E1-46.

18. Chafik A, Essamadi A, Çelik SY, Solak K, Mavi A. Partial purification and some interesting properties of glutathione peroxidase from liver of camel (Camelus dromedarius). Russian Journal of Bioorganic Chemistry. 2018 Jan;44(1):41-51. 
19. Committee for Medicinal Products for Human Use. Guideline on bioanalytical method validation. European Medicines Agency. $2011 \mathrm{Jul}$.

20. Nunes CA, Freitas MP, Pinheiro AC, Bastos SC. Chemoface: a novel free user-friendly interface for chemometrics. Journal of the Brazilian Chemical Society. 2012 Nov;23(11):2003-10.

21. Bahar B, Tuncel AF, Holmes EW, Holmes DT. An interactive website for analytical method comparison and bias estimation. Clinical biochemistry. 2017 Dec 1;50(18):1025-9.

22. Ichihara K, Hosogaya S, Okutani R, Yoshimoto S, Itoh K, Kameko M, Kayamori Y, Takagi Y, Nakano Y, Haga R, Motonaga H. Protocols of determining limits of detection and limits of quantitation for quantitative analytical methods. Japanese Journal of Clinical Chemistry. 2006 Sep 19;35(3):280-94.

23. Payne RB. Method comparison: evaluation of least squares, Deming and Passing/Bablok regression procedures using computer simulation. Annals of clinical biochemistry. 1997 May;34(3):319-20.

24. Giavarina D. Understanding bland altman analysis. Biochemia medica. 2015 Jun 15;25(2):14151.

25. Özyürek M, Güçlü K, Apak R. The main and modified CUPRAC methods of antioxidant measurement. TrAC Trends in Analytical Chemistry. 2011 Apr 1;30(4):652-64.

26. S.C. Ferreira, R.E. Bruns, H.S. Ferreira, G.D. Matos, J.M. David, G.C. Brandao, E.P. da Silva, L.A. Portugal, P.S. Dos Reis, A.S. Souza, W.N. Dos Santos, Box-Behnken design: an alternative for the optimization of analytical methods, Analytica chimica acta, 597 (2007) 17986.

27. Qi X, Ng KT, Lian Q, Li CX, Geng W, Ling CC, Yeung WH, Ma YY, Liu XB, Liu H, Liu J. Glutathione peroxidase 3 delivered by hiPSC-MSCs ameliorated hepatic IR injury via inhibition of hepatic senescence. Theranostics. 2018;8(1):212.

28. Wang R, Yang Z, Zhang J, Mu J, Zhou X, Zhao X. Liver injury induced by carbon tetrachloride in mice is prevented by the antioxidant capacity of Anji white tea polyphenols. Antioxidants. 2019 Mar;8(3):64. 